\title{
Taxation and Budget Reform Commission (TBRC) Constitutional Amendment 9: Requiring 65 Percent of School Funding for Classroom Instruction; State's Duty for Children's Education ${ }^{1}$
}

Rodney L. Clouser²

This amendment was removed from the November 2008 ballot by the Florida Supreme Court. FE748 will be maintained on the EDIS website through December 31, 2008, and then archived for historical purposes.

A series of 16 fact sheets has been written on statutory and constitutional proposals adopted by the Taxation and Budget Reform Commission (TBRC). The publications in this series can be accessed at http://edis.ifas.ufl.edu. Fact sheets FE733 through FE741 address statutory changes and fact sheets FE742 through FE748 address constitutional amendments. These fact sheets should not be considered as an all-inclusive assessment of the statutory or constitutional changes recommended by the Taxation and Budget Reform Commission. Some details of proposed changes may not have been discussed due to space limitations. These fact sheets are not intended as a replacement for personal knowledge about actual or proposed changes but are a guide to inform the public on the issues.

\section{Introduction}

According to Article XI, Section 6 of the Florida Constitution, "Beginning in 2007 and each twentieth year thereafter there shall be established a taxation and budget reform commission." The Taxation and Budget Reform Commission (TBRC) is charged with the following:

examine the state budgetary process, the revenue needs and expenditure processes of the state, the appropriateness of the tax structure of the state, and governmental productivity and efficiency; review policy as it relates to the ability of state and local government to tax and adequately fund governmental operations and capital facilities required to meet the state's needs during the next twenty-year period; determine methods favored by the citizens of the state to fund the needs of the state, including alternative methods for raising sufficient revenues for the needs of the state; determine measures that could be instituted to effectively gather funds

1. This is EDIS document FE748, a publication of the Food and Resource Economics Department, Florida Cooperative Extension Service, Institute of Food and Agricultural Sciences, University of Florida, Gainesville, FL. Published July 2008. Please visit the EDIS website at http://edis.ifas. ufl.edu.

2. Rodney L. Clouser, professor and extension public policy specialist of the Food and Resource Economics Department, Florida Cooperative Extension Service, Institute of Food and Agricultural Sciences, University of Florida, Gainesville, FL.

The Institute of Food and Agricultural Sciences (IFAS) is an Equal Opportunity Institution authorized to provide research, educational information and other services only to individuals and institutions that function with non-discrimination with respect to race, creed, color, religion, age, disability, sex, sexual orientation, marital status, national origin, political opinions or affiliations. U.S. Department of Agriculture, Cooperative Extension Service, University of Florida, IFAS, Florida A. \& M. University Cooperative Extension Program, and Boards of County Commissioners Cooperating. Larry Arrington, Dean 
from existing tax sources; examine constitutional limitations on taxation and expenditures at the state and local level; and review the state's comprehensive planning, budgeting and needs assessment processes to determine whether the resulting information adequately supports a strategic decision-making process.

The TBRC can make statutory recommendations to the Florida Legislature and directly place proposed constitutional amendments on the ballot for approval or rejection by Florida voters.

Fact sheets in this series will present information on constitutional amendments the TBRC has placed on the fall 2008 general election (2008 November presidential election) ballot. The commission was charged with holding public meetings to carry out their responsibilities and has been meeting since March of 2007. The committee concluded their work and transmitted their proposed constitutional amendments to the Florida Secretary of State on April 28, 2008. All the proposed constitutional amendments required an affirmative vote of at least two-thirds of the voting members of the commission (17 members). In total, the TBRC approved eleven constitutional proposals. The committee combined these eleven proposals into seven constitutional amendments. The amendments passed by the TBRC will be numbered Amendments 3 through 9 on the fall ballot (Amendments 1 and 2 are reserved for two other 2008 amendment proposals, one approved by the legislature and the other a citizen initiative).

The TBRC amendments placed on the 2008 general election ballot are listed by ballot title below:

- Amendment 3: Changes and Improvements Not Affecting the Assessed Value of Residential Real Property

- Amendment 4: Property Tax Exemption of Perpetually Conserved Land; Classification and Assessment of Land Used for Conservation

- Amendment 5: Eliminating State Required School Property Tax and Replacing with Equivalent State Revenues to Fund Education
- Amendment 6: Assessment of Working Waterfront Property Based upon Current Use

- Amendment 7: Religious Freedom

- Amendment 8: Local Option Community College Funding

- Amendment 9: Requiring 65 Percent of School Funding for Classroom Instruction; State's Duty for Children's Education

Each fact sheet in this series will provide details regarding one of the amendments, submitted to the Secretary of State, in the order they will appear on the ballot (Amendment 3, Amendment 4, Amendment 5, Amendment 6, Amendment 7, Amendment 8, and Amendment 9).

\section{Proposed Amendment 9}

When people go to their polling places in November 2008, they will see information on the amendment, references to the portion of the constitution that will be altered, sponsor of the amendment, the ballot title, and the ballot summary. The information for Amendment 9 will be similar or identical to the following and the ballot title and ballot summary are direct quotes:

Proposed Constitutional Amendment No. 9: ARTICLE IX, SECTIONS 1 AND 8; ARTICLE XII, SECTION 28 (Taxation and Budget Reform Commission)

\section{Ballot Title: REQUIRING 65 PERCENT OF SCHOOL FUNDING FOR CLASSROOM INSTRUCTION; STATE'S DUTY FOR CHILDREN'S EDUCATION}

Ballot Summary: Requires at least 65 percent of school funding received by school districts be spent on classroom instruction, rather than administration; allows for differences in administrative expenditures by district. Provides the constitutional requirement for the state to provide a "uniform, efficient, safe, secure, and high quality system of free public schools" is a minimum, nonexclusive duty. Reverses legal precedent prohibiting public funding of private school alternatives to public school programs without creating an entitlement. 


\section{Effect of Amendment 9}

Amendment 9 is a combination of two separate proposals passed by the TBRC. One of the proposals deals with the issue of the provision of public services by private providers, including religious providers. The other proposal centers on the issue of requiring $65 \%$ of funding received by school districts to be expended on classroom instruction.

Amendment 9 specifically notes that public funding of education

is a fundamental value of the people of the State of Florida. It is, therefore, a paramount duty of the state to make adequate provision for the education of all children residing within its borders. This duty shall be fulfilled, at a minimum and not exclusively, through adequate provision by law for a uniform, efficient, safe, secure, and high quality system of free public schools.

The key phrase is the language added that states that education is to be fulfilled "at a minimum and not exclusively" through free public schools. Amendment 9 also states the proposed amendment does not "create an entitlement to a publicly-financed private program."

The TBRC state staff analysis cites many of the same issues with Amendment 9 as with proposed Amendment 7. Amendment 7 proposes to repeal the "Blaine Amendment" which was adopted as part of the 1868 Florida Constitution. According to state staff analysis, the Blaine Amendment "was used as the basis, by the First District Court of Appeal ... to invalidate the Opportunity Scholarship Program (OSP). According to state staff analysis, a dissenting opinion in the First District Court of Appeal decision stated that it "would prohibit any religious institution from acting as a government service provider or participating in secular general welfare programs where there is only an incidental benefit to religion" and that "various legislative programs, in addition to Opportunity Scholarships, that eligible persons may utilize at private educational institutions across Florida, including those that are religiously affiliated or operated," might be unconstitutional as well.
According to state staff analysis, the proposed amendment, if passed, would:

- reverse court decisions by repealing the Blaine Amendment.

- permit the legislature to fund private alternatives to public schools.

- allow private individuals to be "educated by a publicly financed, private service provider that meets their unique needs.

The second component of Amendment 9 is the requirement that "at least sixty-five percent of the school funding received by school districts shall be spent on classroom instruction, rather than on administration." The amendment further states that "classroom instruction" and "administration" will be defined by law (i.e., by the legislature). The amendment states that differences in administrative expenditures can be addressed by the legislature, specifically citing transportation and food services as examples. Finally, the amendment specifies that capital outlay expenditures shall not be included in calculating the $65 \%$ classroom requirement. Amendment 9, if passed, would take effect in fiscal year 2009-2010, beginning July 1, 2009.

\section{Impact of Amendment 9}

It is clear that if the amendment is passed, the possibility of school vouchers is "back in play" in Florida. What is unclear concerning the amendment is whether a program such as the Opportunity Scholarship Program would be revived or a new legislative program would be developed. There is no estimated fiscal impact of this change, since no new taxes or fees are anticipated. It is clear, however, that the potential exists for fewer state dollars being allocated to public schools. Yet, that does not necessarily translate into fewer dollars per pupil being spent by the state, which might happen if the value of the voucher is less than the current average spending per pupil.

Many details are left unanswered by the proposal to spend $65 \%$ of funding received by school districts directly on classroom instruction. Critical questions are not answered by the amendment. How will 
classroom instruction be defined? Will funds be spent on libraries and computers contained within classroom instruction? No one knows until the legislature defines the terms of classroom instruction and administration

The concept of $65 \%$ of funding being spent in the classroom is part of a national effort by the group "First Class Education" (FCE) which is based in Washington, D.C. (http://www.firstclasseducation.org/). The group is leading a grassroots effort to get all states to adopt this concept. According to FCE (2008), Florida spends, on average, $59.16 \%$ of funding received on classroom instruction. This ranks Florida 43rd among the 50 states. FCE argues that by increasing this level to $65 \%$, over $\$ 1$ billion more per year would be spent in the classroom. This would be accomplished without raising any taxes or fees. FCE cites the National Center for Educational Statistics as the source data but does not indicate the year.

FCE claims that "if we can get the business side of education to adopt better business practices, we would have more money for the education side of education." While the concept seems reasonable, not all businesses thrive or survive. Successful businesses are well-managed and grow; unsuccessful businesses are mismanaged and fail. The same situation might be expected in educational applications. FCE also implies that spending more money in the classroom will improve student performance. They cite that "research by Colorado's Independence Institute shows the percentage of dollars reaching the classroom has five times greater correlation (49\% correlation) with increased test scores than simply spending more money (10\% correlation)." Standard statistical analysis tools indicate this represents a weak-to-moderate correlation between percentage of dollars spent in the classroom and increased test scores, meaning that more money spent in the classroom is no guarantee of increased student performance.

\section{Summary}

Adoption of the constitutional amendment requires a vote in favor of the amendment by a minimum of $60 \%$ of those voting. Additionally, amendments are subject to legal challenges and could possibly be removed from the ballot if successfully challenged.

Voters in Florida have the opportunity to change the state constitution during the 2008 general election. The intent and purpose of the information contained in this fact sheet on Amendment No. 9 is not to tell individuals how to vote. Rather, the fact sheet is provided to help voters become more informed. Informed voters need to be more knowledgeable of the ballot issue on which they are voting than just by reading a ballot title and ballot summary. Ballot titles and summaries do not inform voters in significant detail, nor do they inform voters on policy implications of what a yes or no vote implies. Because informed voters make informed public policy decisions, your challenge as a voter and a citizen is to become informed and then, by casting your ballot, make your values and preferences known.

\section{References}

First Class Education. 2008. First Class Education Keeps 65 Cents in the Classroom for Teachers and Kids. First Class Education, Washington, D.C. (May). http://www.firstclasseducation.org/

Florida Department of State, Division of Elections. 2008. Initiatives / Amendments / Revisions. Division of Elections, Florida Department of State, Tallahassee, FL (May). http://election.dos.state.fl.us/initiatives/ initiativelist.asp

Florida Taxation and Budget Reform Commission. 2008. A resolution proposing an amendment to Section 1 and the creation of Section 8 of Article IX and the creation of Section 28 of Article XII of the State Constitution. TBRC, Tallahassee, FL (May). http://www.floridatbrc.org/pdf/ Combined26_40FINAL.pdf

Florida Taxation and Budget Reform Commission. 2008. Staff Analysis and Economic Impact Statement. TBRC, Tallahassee, FL (May). 
http://www.floridatbrc.org/pdf/

CP0026FirstHearingAnalysis.pdf

Florida Taxation and Budget Reform

Commission. 2008. Staff Analysis and Economic

Impact Statement. TBRC, Tallahassee, FL (January).

http://www.floridatbrc.org/pdf/

CP0020StaffAnalysis.pdf

Florida Taxation and Budget Reform

Commission. 2008. Staff Analysis and Economic

Impact Statement. TBRC, Tallahassee, FL (May).

http://www.floridatbrc.org/pdf/

CSforCP40AnalysisPBPC3_4_08.pdf

Florida Taxation and Budget Reform

Commission. 2008. Transmittal letter. TBRC,

Tallahassee, FL (May).

http://www.floridatbrc.org/pdf/

CPTransmittalLetter.pdf 